(187)

\title{
Water Quality and Salmonella spp. Contamination Status of Groundwater in Medirigiriya in Polonnaruwa District, Sri Lanka
}

\author{
Mahagamage M.G.Y.L.*, Manage P.M. \\ Centre for Water quality \& Algae Research, Department of Zoology, \\ University of Sri Jayewardenepura, Sri Lanka \\ *m.g.y.l.mahagamage@gmail.com
}

\begin{abstract}
Groundwater is most vital natural resource and it plays a significant role with the drinking, agriculture and domestic sectors. The most important bacterial gastrointestinal diseases such as shigellosis and salmonellosis are transmitted through water and contamination of drinking water by pathogenic bacteria is a major health issue. Therefore, the present study was carried out to identify the microbiological and chemical contamination status of 47 well water sources in Medirigiriya in Polonnaruwa district during March 2017. The study was focused to determine total coliform, feacal coliform, Salmonella spp. and Shigella spp. contamination along with some physico-chemical water quality parameters. Sampling, transportation and analysis were done following standard protocoles. Results of the study revealed that almost all sampling locations were contaminated with both total and fecal coliform bacteria and the values were not within the WHO and SLS drinking water quality standard. 70 percent of sampling locations were positive for Salmonella spp. and Shigella spp. was not recorded during the study period. 40 percent of sampling locations were recorded high conductivity $(750<\mu \mathrm{S} / \mathrm{cm})$ which was not within the guideline values given by the SLS. pH and DO were ranged between 6.28 to 7.98 and 1.62 to $7.78 \mathrm{mg} / \mathrm{L}$ respectively. Majority of the sampling locations were recorded high COD values greater than the Sri Lanka drinking water quality standards $(10 \mathrm{mg} / \mathrm{L})$. The tested other water quality parameters; $\mathrm{N}-\mathrm{NO}_{3}{ }^{-}, \mathrm{N}^{-} \mathrm{NO}_{2}^{-}, \mathrm{N}^{-} \mathrm{NH}_{3}$ and total phosphate (TP) were found within the Sri Lanka drinking water standards.
\end{abstract}

Keywords: Groundwater, Medirigiriya, Water quality, Salmonella spp., Shigella spp. 